\title{
COMMENTS
}

\section{Internet Service of Process: A Constitutionally Adequate Alternative?}

\author{
Rachel Cantor $\dagger$
}

At the end of 1998, there were nearly 150 million users of the internet. ${ }^{1}$ Of the internet users worldwide, almost 52 percent are located in the United States. ${ }^{2}$ The number of users is expected to increase to one billion by the year $2005 .^{3}$ The popularity of the internet stems, in large part, from its unparalleled speed and efficiency in communication and information gathering. The internet's growing popularity and its centrality in daily life require that legislators, judges, attorneys, and litigants consider how the law can best harmess the potential efficiencies of this technology. One arena in which law and internet technology could be especially well integrated is service of process or summons. ${ }^{4}$

$\dagger$ B.S. 1995, Yale University; J.D. Candidate 2000, The University of Chicago.

1 2/10/99 PR Newswire 13:42:00, available online at <http://www.prnewswire.com/cgibin/stories.pl?ACCT=104\&Story=www/story/02-10-1999-003/5/99081\&EI> (visited Mar 3, 1999), citing Computer Industry Almanac Inc as the source for the statistics.

3 Id.

- Computer Industry Almanac, Computer Industry Says Over 364 Million PCs-in-Use Worldwide Year-End 1998 (Mar 1999), available online at http//www.c-i-a.com/19903pc use.htm (visited Apr 21, 1999).

- See generally David D. Siegel, Supplementary Practice Commentaries, 28 USCA Rule 4 \& C4-4 ("Practice Commentaries") (defining process as "any paper whereby a person is subjected to a court's jurisdiction" and noting FRCP 4's prior reference to service of process and its current, more appropriate reference to service of summons); Frank Conley, Comment, :-) Service With a Smiley: The Effect of E-Mail and Other Electronic Communications on Service of Process, 11 Temp Intl \& Comp I J 407 (1997). Throughout this Comment, service of process and service of summons will be used interchangeably. Unless otherwise mentioned, the discussion will focus on service to an individual defendant, not an infant, incompetent, corporation, foreign country, or government body. 
Proper service of summons is essential to any litigation; only after a summons is properly served can a court exercise personal jurisdiction over a defendant. ${ }^{5}$ Service of summons must satisfy both constitutional due process standards and the provisions of the applicable state or federal rule governing service. In federal courts, service of summons is governed by Federal Rule of Civil Procedure 4 ("Rule 4").

Litigants are likely to employ widely used technologies, such as the internet, for service of process before rulemakers review whether it is appropriate to change or reinterpret existing laws to incorporate such technologies. ${ }^{6}$ Litigants employed fax and private express delivery for service purposes because those methods were reliable and efficient, and seemed therefore appropriate. For similar reasons, litigants. will employ internet technology for service purposes. The internet is not only commonly and widely used, but also incredibly fast and inexpensive as a means of effecting service.

This Comment considers whether internet service satisfies the requirements of constitutional due process and applicable rules governing procedure. Part I details the basic requirements for service and lays out a framework for analyzing different methods of service. Part II elucidates a standard for constitutionally adequate alternative service and surveys the formal requirements of federal and state rules governing service. Part III looks at the use of internet technology in the law today, focusing in particular on using internet technology for notice purposes. Part IV describes how the internet can be used to serve process, concentrating on the use of electronic mail. It then analyzes the sufficiency and necessity of internet service of process through the constitutional due process and rule-based framework developed in Parts I and II, concluding that internet service of process does not meet the procedural rule-based requirements of the current Federal Rules, except in those limited circumstances where internet service satisfies the procedural rule-based requirements of the appropriate state rule governing service.

\footnotetext{
S See Siegel, Practice Commentaries $\S$ C4-1 (cited in note 4) ("[A]s demanding as Rule 4 may be, a mistake in its use can be fatal.").

- For instance, service of process by fax and private express delivery services was employed by enterprising litigants, with mixed success, long before rules committees and state legislatures responded. See Part II.B.4, discussing service by fax and private express delivery.
} 


\section{THE STRUCTURE OF SERVICE}

In federal courts, although a civil action begins when the plaintiff files a complaint with the court, ${ }^{7}$ the court cannot constitutionally exercise jurisdiction over both parties until the defendant is properly served with the summons and the complaint. Initial service, as described in Rule 4, serves both notice and evidentiary functions. Notice is fulfilled by giving the defendant a copy of both the complaint, listing the claims against her, and a copy of the summons, ${ }^{8}$ identifying the court in which the action is proceeding, the plaintiff's name, the plaintiff's attorney's address, and the time and place the defendant is required to appear. ${ }^{9}$ Service of the summons also provides proof of the official existence of the action, since the summons must be signed by the clerk of the court and marked with the court's official seal. ${ }^{10}$

Proper service has both constitutional due process and rulebased requirements. The notice function of service protects the defendant's Fifth and Fourteenth Amendment rights not to be deprived of life, liberty, or property without due process of law. ${ }^{11}$ A fundamental component of due process is the opportunity to be heard; ${ }^{12}$ that opportunity is worthless unless the defendant is aware that there is a matter pending against her. ${ }^{13}$ Since properly effected service meets due process requirements, it allows the court-a state actor-to have jurisdiction over an action that may result in deprivation of the defendant's property without violating the defendant's constitutional rights.

The rule-based requirement of service reinforces the constitutional right to due process by providing statutorily defined minimum procedures for effecting service. To effect proper service, a plaintiff must employ methods that comport with the formal requirements of the applicable federal or state rule governing service. ${ }^{14}$ Even if a defendant has actual notice of the action, the court can exercise personal jurisdiction over the defendant only if she was served according to the specific requirements of the ap-

7 FRCP 3.

- FRCP 4(c)(1).

- FRCP 4(a).

${ }^{10}$ Id.

" US Const, Amend V; id Amend XIV \& 1.

${ }^{12}$ Mullane v Central Hanover Bank \& Trust Co, 339 US 306, 314 (1950) (identifying the opportunity to be heard as the "fundamental requirement" of due process); Grannis $v$ Ordean, 234 US 385, 394 (1914) (same).

"Mullane, 339 US at 314.

"See Part II.B.2-3. 
plicable rule; ${ }^{15}$ if the rule's requirements were not met, there is no jurisdiction.

In general, courts prefer personal service, whereby the defendant is handed a copy of the summons and the complaint, ${ }^{16}$ because it "guarantees actual notice of the pendency of a legal action. ${ }^{17}$ However, it is sometimes impossible or exceedingly inefficient to serve the defendant personally. ${ }^{18}$ Thus, most service rules also provide for alternative or substitute forms of service such as mail service or service by leaving copies of the papers at the defendant's home with a mature resident. ${ }^{19}$

Service of process is not the only service that occurs during the litigation process. After the initial service of the summons and the complaint, other papers, such as discovery requests, motions, and offers of judgment, must be served on the opposing party. Federal Rule of Civil Procedure 5 ("Rule 5") governs service of papers other than the initial summons. ${ }^{20}$ Like service of summons, service of other papers fulfills a notice function by informing the opposing party of the serving party's most recent action in the litigation. However, service of other papers is not governed by the same stringent due process standards as service of summons since the defendant already has notice of the action and is aware of the interest at stake. Despite these differences, evaluations of alternative Rule 5 service methods can be instructive in evaluating alternative Rule 4 service methods. ${ }^{21}$

\footnotetext{
${ }^{15}$ See, for example, Dahl v Kanawha Investment Holding Co, 161 FRD 673, 681 (N D Iowa 1995) (holding that indications of the defendant's actual notice of the action do not "dispense with the requirements for proper service of process" when procedural rules are not complied with).

${ }^{16}$ See Greene $v$ Lindsey, 456 US 444, 449 (1982) (noting that personal service presents the "ideal circumstance under which to commence legal proceedings").

${ }^{17} \mathrm{Id}$.

"See, for example, Manufacturers Hanover Trust Co $v$ Ponsoldt, 51 F3d 938, 941 (11th Cir 1995) (holding substituted service of process by state law sufficient, particularly in light of defendant's successful attempts to avoid personal service); New England Merchants National Bank $v$ Iran Power Generation and Transmission Co, 495 F Supp 73, 7981 (S D NY 1980) (directing plaintiffs to serve Iranian defendants by telex after defendants successfully resisted service despite their knowledge of the action).

${ }^{19}$ See FRCP 4(e) (providing for (1) personal service, (2) service "by leaving copies . . . at the individual's dwelling house or usual place of abode with some person of suitable age and discretion then residing therein or by delivering ... to an agent authorized by appointment or by law to receive service of process," or (3) service pursuant to state law).

${ }^{20}$ See FRCP 5(a).

${ }^{21}$ Compare Magnuson v Video Yesteryear, 85 F3d 1424, 1430 (9th Cir 1996) (determining the adequacy of Federal Express service under Rule 5 and looking to judicial interpretation of Rule 4 for guidance).
} 


\section{Alternative Methods of Service}

\section{A. The Constitutional Standard for Exercising Alternative Service}

The Supreme Court has laid out a reasonableness standard for determining the validity of alternative forms of service..$^{22}$ This standard is driven by "the traditional notions of fair play and substantial justice implicit in due process"23 and based on the same cost-benefit considerations outlined by the Court in Mathews $v$ Eldridge.$^{24}$ Ultimately, whether a method of service is reasonably calculated to give actual notice to the defendant is determined in light of the nature of the particular action, ${ }^{25}$ the circumstances of the particular case,${ }^{25}$ and the availability of alternative reliable, cost effective forms of service. ${ }^{27}$

\section{The development of the reasonableness standard.}

In Mullane $v$ Central Hanover Bank \& Trust $\mathrm{Co}^{28}$ the Supreme Court set out the constitutional notice requirements for service of process. There must be "notice reasonably calculated, under all the circumstances, to apprise interested parties of the pendency of the action and afford them an opportunity to present their objections. ${ }^{\text {"29 }}$ The Court in Mullane found that the constructive notice employed in the case, publication in a New York newspaper, was constitutionally inadequate because it was not reasonably calculated to notify all individuals who could easily have been reached.$^{30}$ Despite the fact that the trust involved in

${ }^{22}$ See Milliken $v$ Meyer, 311 US 457, 463 (1940) (noting that "so far as due process is concerned [adequacy] is dependent on whether or not the form of substituted service ... is reasonably calculated to give... actual notice").

${ }^{23}$ Id (internal citations omitted).

24 424 US 319, 335 (1976).

is See Mullane v Central Hanover Bank \& Trust Co, 339 US 306, 313 (1950) (noting that the Due Process Clause requires "notice and opportunity for hearing appropriate to the nature of the case").

${ }^{28}$ See Greene $v$ Lindsey, 456 US 444, 451 (1982) (noting that the constitutionality of a method of service is determined in relation to the "realities of the case" at issue).

${ }^{27}$ See id at 454 ("Of course, the reasonableness of the notice provided must be tested with reference to the existence of 'feasible and customary' alternatives and supplements to the form of notice chosen."), quoting Mullane, 339 US at 315.

339 US 306 (1950).

20 Id at 314 (internal citations omitted).

so Id at 315. Notably, the Court recognized that constructive notice was sufficient for those parties whose addresses could not be discovered with due diligence. Id at 317. Thus, the finding of constitutional inadequacy was expressly limited to those parties whose whereabouts were known. Id at 318. The fact that the Court limited its holding to those parties whose addresses were known is a strong indication that the reasonableness analysis is to be conducted on a case-by-case basis; that is, that the reasonableness of a notice 
the case had records of the names and addresses of many of the parties, the trust failed to mail notice to those parties, ${ }^{3 !}$ and the published notice did not name the individuals it was meant to inform. ${ }^{32}$

In Greene $v$ Lindsey, ${ }^{33}$ the Supreme Court again considered the validity of an alternative form of service made pursuant to a state law. In Greene, the Housing Authority of Louisville sought to remove the plaintiffs from their apartments and commenced detainer actions against them. ${ }^{34}$ The sheriff, after attempting unsuccessfully to effect personal service, posted notices of eviction on the apartment doors of each of the plaintiffs pursuant to the state law governing service in detainer actions. ${ }^{35}$ Each plaintiff claimed that he or she failed to receive notice. ${ }^{36}$ The Court emphasized that the reasonableness of a particular method of service is determined by reference to the facts of the case under consideration. ${ }^{37}$ While the Court conceded that posting notice might be appropriate under certain circumstances, ${ }^{38}$ it determined that posting alone was an inadequate means of affording notice under the particular circumstances of the case. ${ }^{39}$

Read together, Mullane and Greene emphasize that courts interpret the constitutional requirements of due process as a strong commitment to service methods calculated to afford actual notice to defendants. Nevertheless, the cases require something short of actual notice, setting a standard of reasonableness for

procedure turns on specific information about the particular parties to the action.

31 Id at 318.

32 Id at 315 .

ss 456 US 444 (1982).

"Id at 446.

${ }^{3}$ Id.

${ }^{35}$ Id at 453.

${ }^{7}$ See, for example, id at 451 ("In arriving at the constitutional assessment, we look to the realities of the case before us.").

${ }^{38}$ Id at 452 ("The empirical basis of the presumption that notice posted upon property is adequate to alert the owner or occupant of property of the pendency of legal proceedings would appear to make the presumption particularly well founded where notice is posted at a residence.").

${ }^{39}$ Id at 453-54 (noting the testimonies of the process servers that notices were sometimes torn down and concluding that "[u]nder these conditions, notice by posting on the apartment door" was not reliable). See also note 30 . It is important to note that the Supreme Court did not rule that mail service was the required means of alternative service. Rather, the Court used mail service, an obvious, reliable means of service, to exemplify the unreasonableness of the alternative form of service chosen. Id at 455 ("WW]here an inexpensive and efficient mechanism such as mail service is available to enhance the reliability of an otherwise unreliable notice procedure, the State's continued exclusive reliance on an ineffective means of service is not notice 'reasonably calculated to reach those who could easily be informed by other means at hand." ), quoting Mullane, 339 US at 319. 
the employment of alternative forms of service. ${ }^{40} \mathrm{Greene}$ and $\mathrm{Mul}$ lane do not require use of the alternative method of service most likely to reach the defendant; instead, they require only the use of a method of service reasonably calculated to reach the defendant given the circumstances of the case. ${ }^{41}$

\section{The due process factors and the reasonableness standard.}

The reasonableness inquiry for evaluating alternative forms of service comports with the due process considerations announced in Mathews: (1) the private interest that will be affected, (2) the risk of mistakenly depriving an individual of her interests through the use of the procedure in question and the "probable value ... of additional or substitute procedural safeguards," and (3) the government interest that will be affected by amending the procedure, such as the financial and administrative costs that alternative procedures might impose. ${ }^{42}$

In Mullane and Greene, the Court first identified the individual interest at stake through consideration of the nature of the action. ${ }^{43}$ In Greene the interest at stake was the defendants' "continued residence in their homes,"44 while in Mullane the interests at stake were the beneficiaries' rights to have a trustee answer to them for impairments of their interests and to protect the overall value of their shares. ${ }^{45}$ Next, in both Greene and Mullane, the Court evaluated the "reasonableness" of the service method employed, comparing the effectiveness of the service method at issue with that of other available methods (in both cases, this other method was mail). ${ }^{46}$ The Court's reasonableness inquiry in these

${ }^{+}$Mullane, 339 US at 315 ("The reasonableness and hence the constitutional validity of any chosen method may be defended on the ground that it is in itself reasonably certain to inform those affected or, where conditions do not reasonably permit such notice, that the form chosen is not substantially less likely to bring home notice than other of the feasible and customary substitutes.") (internal citations omitted).

"Greene, 456 US at 455 ("We need not go so far as to insist that in order to 'dispense with personal service the substitute that is most likely to reach the defendant is the least that ought to be required."'), quoting McDonald v Mabee, 243 US 90, 92 (1917).

"Mathews, 425 US at 335. In Mathews, the Court held that due process does not require an evidentiary hearing be held before one's disability benefits are terminated. Id at 349.

45 Greene, 456 US at 450 ("The character of the action reflects the extent to which the court purports to extend its power, and thus may roughly describe the scope of potential adverse consequences to the person claiming a right to more effective notice.") (emphasis added).

"Id at 451.

${ }^{45}$ Mullane, 339 US at 313.

is Id at 318; Greene, 456 US at $454-55$. 
cases was in essence equivalent to the second Mathews factor, which balances the risk of depriving individuals of their interests against the costs and value of additional safeguards. ${ }^{47}$ Finally, both the reasonableness standard for evaluating alternative forms of service and the third Mathews factor require consideration of the costs of the challenged procedure relative to available alternatives. ${ }^{48}$ For instance, because of "the practical difficulties and costs" that would be incurred locating unknown beneficiaries, the Court in Mullane limited its holding that publication was constitutionally inadequate to those cases in which the whereabouts of interested parties were known. ${ }^{49}$

\section{B. Alternative Service Under the Federal Rules}

1. (In)sufficiency of actual notice.

Even if an alternative form of service passes constitutional muster under the reasonableness standard of Mullane and Greene, it may not be sufficient. Most courts hold that service is invalid when it does not comply with the provisions of the applicable rule, even if the defendant has actual notice of the action. ${ }^{50}$ Many of the cases discussing the insufficiency of actual notice were generated under the 1983 version of Rule $4 .^{51}$ These cases resulted from the confusion generated by the old Rule about the

Mathews, 424 US at 335.

48. Id.

19 Mullane, 339 US at 317-18. See also Greene, 456 US at 455 (noting specifically that mail service, the supplemental procedure weighed against the procedure in question, was "inexpensive").

${ }^{50}$ See Ayres $v$ Jacobs \& Crumplar, PA, 99 F3d 565, 568-70 (3d Cir 1996) (holding defendant's actual notice, as evidenced by participation in discovery, failed to confer jurisdiction because summons was not issued and signed by the clerk nor stamped with the seal of the court); McGann $v$ New York, 77 F3d 672, 675 (2d Cir 1996) (holding plaintiff's attempt to effect mail service insufficient despite defendant's actual notice because plaintiff failed to include an acknowledgement form as required by state law); Gulley v Mayo Foundation, 886 F2d 161, 165 (8th Cir 1989) (holding that mail service is not effective, even when the return receipt card is signed and received by the serving party, unless the defendant also returns the acknowledgment of service form); Armco, Inc $v$ Penrod-Stauffer Building Systems, Inc, 733 F2d 1087, 1088-89 (4th Cir 1984) (voiding default judgment where service, despite actual notice, was insufficient to establish personal jurisdiction over defendant who failed to acknowledge receipt of summons and complaint); Maryland State Firemen's Association v Chaves, 166 FRD 353, 355 (D Md 1996) (holding entry of default judgment improper where service of process was invalid, despite defendant's actual receipt of mailed service); Dahl v Kanawha Investment Holding Co, 161 FRD 673, 681 (N D Iowa 1995) (holding that return receipts signed by defendants indicating actual notice do not "dispense with the requirements for proper service of process"). Similarly, actual notice is usually not sufficient under Rule 5. See Magnuson v Video Yesteryear, 85 F3d 1424, 1431 (9th Cir 1996) (adopting rule that would excuse a party's failure to comply with Rule 5 upon a showing of "exceptional good cause").

si The current version of Rule 4 was adopted in 1993. See Part II.B.2. 
adequacy of mail service received by a defendant (as evidenced by a defendant's signature on a return receipt form), but not acknowledged (through return to the plaintiff of the required acknowledgement form). Although the 1993 amendments to Rule 4 eliminate much of the confusion by providing a more carefully drafted waiver provision, ${ }^{52}$ court discussions about the sufficiency of actual notice generated under the old Rule 4 are still relevant as evidence of the dual requirements of service: constitutional due process and rule-based adequacy.

Despite the amendments to Rule 4, the issue of actual notice continues to arise, ${ }^{53}$ even within the context of service by mail. ${ }^{54}$ Although most cases are resolved in favor of the rule requiring procedurally adequate service, ${ }^{55}$ the Second Circuit and a few

${ }^{52}$ See The New (Dec. 1, 1993) Rule 4 Of The Federal Rules Of Civil Procedure: Changes In Summons Service And Personal Jurisdiction, 151 FRD 441, 455 (1994) (discussing the confusion under the old Rule concerning whether unacknowledged mail service constituted service, citing the major cases, and stressing that "a similar issue should not arise under the waiver procedure of the new FRCP 4, even though it is in effect a replacement of the old service-by-mail provision under which all the above cases arose").

${ }^{83}$ See, for example, Ayres, 99 F3d at 568-70 (holding actual notice insufficient where procedural rules not followed in service of summons); DeFazio v Delta Air Lines, Inc, $849 \mathrm{~F}$ Supp 98, 103 (D Mass 1994) (holding actual notice insufficient where plaintiff could not show good cause why defendants were never properly served); Koehl v Rowe, DDS, 1997 WL 724647, *7-8 (E D NY) (holding actual notice sufficient where pro se plaintiff was not at fault for failure of service, since US Marshals had twice unsuccessfully attempted service on defendant).

${ }^{34}$ See, for example, Oltremari v Kansas Social \& Rehabilitative Service, 871 F Supp 1331, 1348-50 (D Kan 1994) (applying Kansas civil procedural rule to reject defendant's contention that summons was insufficient because allegedly improperly addressed); Maryland State Firemen's Association, $166 \mathrm{FRD}$ at 355 (holding actual receipt of mailed service insufficient notice to support default judgment against defendants); Dahl, 161 FRD at 681 (noting that actual notice is insufficient if rule-based requirements for service are not met); Tadros v Public Employees Federation, 1995 US Dist LEXIS 18678, *12 (S D NY) (construing Rule 4 liberally to find that pro se plaintiff had properly served defendants even though plaintiff had failed to include a waiver of service with the summons; defendants had actual notice).

${ }^{s s}$ See, for example, Ayres, 99 F3d at 568-70; DeFazio, 849 F Supp at 103; Maryland State Firemen's Association, 166 FRD at 355; Dahl, 161 FRD at 681. But see Oltremari, 871 F Supp at 1350 (holding mail service sufficient despite the failure of defendants to return the acknowledgment of service forms; defendants signed the return receipts, did not contest that they received service, and did not contest that service complied with due process); Koehl, 1997 WL 724647 at *7-8 (finding lack of strict compliance with Rule 4 procedures harmless error given that plaintiff proceeded pro se, defendant received actual notice, and defect in service was the US Marshal's fault); Tadros, 1995 US Dist LEXIS 18678 at *12 (finding actual notice received through service by mail sufficient despite plaintiff's failure to include waiver forms; plaintiff proceeded pro se and thus the Federal Rules should be construed liberally). Other courts have held that actual notice is sufficient so long as the plaintiff substantially complies with the appropriate rule governing procedure. See United States v Casciano, 124 F3d 106, 113-14 (2d Cir 1997) (applying Massachusetts law); Ortiz $v$ County of Westchester, 1994 US Dist LEXIS 11147, *5-9 (S D NY) (applying Rule 4); Wagner v Truesdell, 1998 SD 9, 574 NW2d 627, 629 (1998) (applying South Dakota law). 
other courts still adhere to the rule ${ }^{56}$ that service is sufficient to confer jurisdiction on a court so long as it results in actual notice. ${ }^{57}$ The minority rule is noteworthy because, in effect, the rule relies completely on the constitutional element of service-due process-and eliminates altogether the requirement of adherence to the applicable rule.

\section{Federal Rule of Civil Procedure 4.}

Under Rule 4 the plaintiff is required to serve the defendant (1) by personal service, (2) by specified alternative methods of service, or (3) "pursuant to the law of the state in which the district court is located, or in which service is effected." ${ }^{358}$ The alternative methods of service expressly recognized in Rule 4 include leaving copies of the summons and complaint at the defendant's "dwelling house or usual place of abode with some person of suitable age and discretion then residing therein" or delivering service to an authorized agent. ${ }^{59}$ Although Rule 4 does not expressly provide for official service of summons by mail or internet, such

${ }^{s 6}$ The Second Circuit's rule was announced in Morse $v$ Elmira Country Club, 752 F2d 35 (2d Cir 1984). In Morse the plaintiff served the defendant by certified mail under pre1993 Rule 4. Id at 36 . The defendant signed the return receipt but never returned the offcial acknowledgment of service. Id. The court was swayed by "strong factors of justice and equity" that "push toward" finding effective service where the defendant actually received the mail service but offered no adequate explanation for the refusal to return the acknowledgment of service. Id at 40 ("Congress would have no ground for providing that proper and known mail service would become ineffective simply because the defendant, without reason, acted like the dog in the manger.") (footnote omitted).

$\sigma$ Courts explicitly following Morse after the 1993 amendments include Allied SemiConductors International, Ltd v Pulsar Components International, Inc, 907 F Supp 618, 622 (E D NY 1995) (holding that "strong factors of justice and equity" favor a finding of effective service where summons is mailed pursuant to Rule 4 and received by defendants); Hurlburt v Zaunbrecher, 169 FRD 258, 259 (N D NY 1996) (preserving incarcerated pro se plaintiff's complaint where defendant had notice and US Marshal failed to execute proper service); Tellier $v$ Reish, 1996 US Dist LEXIS 19076, *5-7 (S D NY) (noting that failure of US Marshals to effect service on behalf of plaintiff proceeding in forma pauperis would be good cause for not fulfilling rule-based requirements for service). But see McGann, 77 F3d at 674 (distinguishing the case from Morse on the grounds that the plaintiff in Morse sent all of the proper documents, while McGann failed to send the acknowledgement form); Nossek v Board of Education of Duanesburg Central School District, 1994 US Dist LEXIS $14146, * 7-8$ (N D NY) (finding that plaintiffs failure to include an acknowledgment form is not fatal to service; however, defendant's failure to return the acknowledgment form then required plaintiff to use another form of service before proceeding). A few other courts seem to have followed the Second Circuit view. See, for example, Richardson v Alliance Tire and Rubber Co, Ltd, 158 FRD 475, 482 (D Kan 1994) (finding substantial compliance and actual notice sufficient for valid service of process under Kansas law). See also Kan Stat Ann $\S 60-204$ (1983) (providing that actual notice is sufficient so long as the serving party substantially complies with the rule governing service).

${ }^{88}$ FRCP 4(e)(1).

s9 FRCP 4(e)(2). 
service would fulfill the Rule's requirement if the action was brought or the defendant was served in a state that provided for service by these means.

Rule 4 also includes a waiver provision that allows defendants to waive service of process. ${ }^{60}$ In 1983 the Rule was amended, in part, to broaden the forms of alternative service available to plaintiffs. ${ }^{61}$ The 1983 amendments created many problems and conflicts among the courts ${ }^{62}$ that led to further amendments in 1993. In particular, courts interpreted the 1983 amendments to Rule 4 as establishing first class mail as an alternative means of service. ${ }^{63}$ However, the 1983 amendments were intended only to create a procedure by which a plaintiff could use the mail to request that a defendant waive her right to formal service of process. ${ }^{64}$ Thus, one of the principal changes of the 1993 amendments was to replace the first class mail provision with a more appropriately named waiver provision now codified in Rule 4(d) ${ }_{6}^{65}$ The waiver provision allows a plaintiff to use

\footnotetext{
s FRCP 4(d).

"I See generally Kent Sinclair, Service of Process: Rethinking the Theory and Procedure of Serving Process Under Federal Rule 4(c), 73 Va L Rev 1183, 1212-13 (1987) (discussing the "sweeping authorization for service by mail in federal courts" granted by the 1983 amendments to Rule 4). See also Amendments to the Federal Rules of Civil Procedure, 93 FRD 255, 259 (1982) (discussing amendments to Rule 4 necessitated by the limited funds available to the US Marshal's Service).

* See, for example, David S. Welkowitz, The Trouble with Service by Mail, 67 Neb L Rev 289, 291 (1988) (identifying and discussing three issues that arose concerning the 1983 first class mail provisions of Rule 4: determining (1) when service had actually been made, (2) whether mail service could be used for defendants who resided in other states, and (3) what procedures could be used to effect service when a defendant failed to return an acknowledgement form); Ann Varnon Crowley, Note, Rule 4: Service by Mail May Cost You More Than a Stamp, 61 Ind I J 217, 225-38 (1986) (discussing problems that arose applying Rule 4 after the 1983 amendments).

es Prior to the 1993 amendments, under Rule 4, a plaintiff could serve summons and complaint:

by mailing a copy of the summons and of the complaint (by first class mail, postage prepaid) to the person to be served, together with two copies of a notice and acknowledgment . . . form . . . and a return envelope, postage prepaid, addressed to the sender. If no acknowledgment of service under this subdivision of this rule is received by the sender within 20 days after the date of mailing, service of such summons and complaint shall be made [by personal service or substituted service by delivery to an appropriate person living at the defendant's abode].

FRCP 4(c)(2)(C)(ii) (1992).

" See FRCP 4 Advisory Committee Notes, 1993 Amendments ("The former text described this process as service-by-mail. This language misled some plaintiffs into thinking that service could be effected by mail without the affirmative cooperation of the defendant. ... It is more accurate to describe the communication sent to the defendant as a request for a waiver of formal service.").

" FRCP 4(d)(2) now reads:
}

An individual ... that is subject to service ... and that receives notice of an action in the manner provided in this paragraph has a duty to avoid unnecessary costs of 
mail or "other reliable means" to request that a defendant waive personal service. ${ }^{66}$ The Advisory Committee specifically acknowledged that "electronic communications" may be more convenient to the parties as a method for communicating waiver requests. ${ }^{67}$

\section{State rules. ${ }^{68}$}

Because Rule 4 does not expressly provide for internet service, state rules must be examined to determine whether such service could ever be deemed proper in federal court. Absent a state rule specifically allowing internet service or service methods utilizing electronic mail, the procedural adequacy of internet service will turn on whether the applicable state rule goverming service provides for service by mail and whether electronic mail constitutes "mail."

At least fifteen states explicitly provide for alternative service of process by mail, ${ }^{69}$ and two states provide for service through

serving the summons. To avoid costs, the plaintiff may notify such a defendant of the commencement of the action and request that the defendant waive service of a summons. The notice and request

(A) shall be in writing and shall be addressed directly to the defendant, if an individual ...;

(B) shall be dispatched through first-class mail or other reliable means;

(C) shall be accompanied by a copy of the complaint and shall identify the court in which it has been filed;

...

(E) shall set forth the date on which the request is sent;

$\cdots$

(G) shall provide the defendant with an extra copy of the notice and request, as well as a prepaid means of compliance in writing.

"Saiver of service can be requested of defendants that are individuals, corporations, or associations but not of governmental defendants, infants, or incompetents. FRCP $4(d)(2)$.

${ }^{67}$ FRCP 4(d)(2)(B) Advisory Committee Notes, 1993 Amendments.

the following compilation excludes consideration of service rules for specific actions, for instance, in rem actions, which generally allow for service by publication or mail. See, for example, ICCS ch 735, § 5/2-206 (Supp 1998).

* States that allow service of process by mail: Alabama, Ala R Civ P Rule 4.1 (Michie 1996) (certified mail); Indiana, Ind St Trial P Rule 4.1 (West 1996) (certified or registered mail or "other public means"); Kansas, Kan Stat Ann § 60-303 (1997) (certified mail is the default form of service); Kentucky, Ky R Civ P 4.01(1)(1) (Michie 1999) (certified or registered mail); Michigan, Mich Ct R 2.105 (1998) (certified or registered mail); Nebraska, Neb Rev Stat § 25-505.01(1)(c) (1985) (certified mail); North Carolina, NC R Civ P 4(j) (1997) (registered or certified mail); North Dakota, ND R Civ P 4 (1987) ("any form of mail" that requires a "signed receipt"); Ohio, Ohio R Civ P 4.1 (Baldwin 1995 \& Supp 1998) (certified or express mail); Oklahoma, 12 Okla Stat Ann $\$ 200$ A2 (West 1998); Oregon, Or R Civ P $7 D(2)(d)$ (1996) (first class and by certified, registered, or express mail); South Carolina, 
other means such as facsimile. ${ }^{70}$ Other states have mail service procedures that are similar to Rule 4, in which mail service is adequate only if acknowledged by the defendant; this procedure is more properly described as one for waiver of service. ${ }^{71}$ Still other states define the acceptable methods for service of process narrowly and thereby omit the possibility of service of process by mail altogether. ${ }^{72}$ Finally, a limited number of states provide for service of process by mail as a last resort when the traditional forms of service, such as personal service and leaving a copy at the defendant's home, fail. ${ }^{73}$

SC R Civ P 4(d)(8) (1997) (registered or certified mail); Tennessee, Tenn R Civ P 4.04(12) (1996) (registered or certified mail); Washington D.C., DC R Civ P 4(c)(3) (1998); West Virginia, W Va R Civ P 4(d)(1) (Michie 1995) (certified mail or first class mail).

${ }_{70}$ Idaho, Idaho R Civ P 4(c)(3) (Michie 1997) (facsimile or telegraph); Montana, Mont Code Ann $\S 25-3-501$ (1997) (service of summons by telephonic or telegraphic copy).

"At least thirteen states have waiver or quasi-waiver provisions: Arizona, Ariz Rev Stat R Civ P Rule 4.1 (1987 \& Supp 1998); California, Cal Civ Pro Code $\$ 415.30$ (West 1997); Maine, Me R Civ P 4(c)(1) (1998); Minnesota, Minn R Civ P 4.05 (1996 \& Supp 1998); Mississippi, Miss R Giv P 4(c)(3)(A) (1998); Missouri, Mo R Civ P 54.20 (Vernon 1976 \& Supp 1998); Montana, Mont R Civ P 4D(1)(b)(i) (1998); New Jersey, NJ R Super Tax Surr Cts 4:4-4(c) (1992) (mail service of process effective only if party files answer to appear within sixty days); New Mexico, NM St Dist Ct $R$ Civ P Rule 1-004(E) (Michie 1999) (mail service ineffective if not responded to within twenty days); New York, NY CPLR § 312-a (McKinney 1990 \& Supp 1999); Rhode Island, RI R Civ P 4(d) (Michie 1998); South Dakota, SD Cod Laws § 15-6-4(i) (Michie 1997); Vermont, Vt R Civ P 4(1) (1988 \& Supp 1997); Wyoming, Wyo R Civ P 4(o) (Michie 1998).

${ }_{72}$ At least seven states do not provide for any form of mail service: Colorado, Colo Rev Stat Ann R Civ P 4 (West 1998) (allowing mail service only for in rem proceedings); Florida, Fla Stat Ann $\$ 48.031$ (3) (West 1994 \& Supp 1998) (allowing mail service only in misdemeanor criminal context); Hawaii, Hawaii R Civ P 4(h) (1995); Illinois, ILCS ch 735, \$ 5/2-203 (Michie Supp 1998); Massachusetts, Mass R Civ P 4(e) (1982 \& Supp 1995) (allowing mail service only to parties outside Commonwealth so long as acknowledgment of receipt is returned by the served party); Nevada, Nev R Civ P 4 (1997).

7 States specifically allowing for mail service of process as a last resort: Connecticut, Conn Gen Stat Ann \$ 52-57(f)(1) (West 1997) (certified mail); New Jersey, NJ R Super Tax Surr Cts 4:4-4(a)(2) (1998); Utah, Utah R Civ P 4(g) (Michie 1998) (allowing for service by mail or other means in extreme circumstances, such as if the person is avoiding service or it is impractical to serve the person, and only upon grant of a motion by the court); Washington, Wash Rev Code Ann $\S 4.28 .080$ (16) (West 1998 \& Supp 1999) (requiring that where party cannot be personally served through reasonable diligence, effective service may be made by both mailing and personally delivering process to mailing address); Wisconsin, Wis Stat Ann $\S 801.11$ (c) (1997). See also Georgia, Ga Code Ann § 9-11-4(i) (1993 \& Supp 1998) (allowing courts to prescribe methods of service when the provisions of the appropriate law governing service are not clear, so long as the methods prescribed are consistent with the Constitution); Iowa, Iowa R Civ P 56.2 (1997) (allowing courts to prescribe alternative methods of service when the statutorily defined methods fail, so long as the prescribed method is consistent with due process). 


\section{Innovative alternative methods of service-what constitutes mail?}

The procedural adequacy of service effected through electronic mail ("email") may rest on whether electronic mail can properly be characterized as "mail" under the Federal Rules or applicable state rules. Although nothing in Rule 4 expressly provides for internet service, Rule 4(e)(1) allows litigants to rely on state rules governing procedure. It follows that if a state rule provides for mail service and email constitutes "mail" under the applicable state rule, then internet service is adequate under Rule 4 (even if the state rule does not expressly allow for internet service).

Prior court determinations of what constitutes mail under the Federal Rules are instructive for determining whether electronic mail is "mail." In the past, litigants attempted to characterize private express delivery services and fax service as mail or certified mail with varying results. ${ }^{75}$

a) Private express delivery service. The majority view holds that private express delivery service does not constitute "mail" under state or federal rules governing notice procedures and therefore is not an adequate form of service. ${ }^{76}$ In Magnuson $v$ Video Yesteryear ${ }^{77}$ the Ninth Circuit ruled that service by Federal

"Note that under the Federal Rules, whether email constitutes "mail" is only important in the Rule 5 context and in the Rule 4 waiver context. Under Rule 4, internet service can properly be employed as a means of alternative service-and not merely as a means for effecting waiver of service-only if the applicable state rule governing service allows for internet service. However, the following discussion focuses on the characterization of fax and private express delivery services as "mail" under the Federal Rules, because the state courts cite federal cases discussing these issues as precedent. It follows that the federal court cases are representative of the line of reasoning employed by most courts considering these issues.

${ }^{75}$ The question of whether private express delivery service constitutes "mail" under the Federal Rules has arisen in both Rule 4 and Rule 5 contexts, while the validity of fax service has arisen mainly in the Rule 5 context. See generally Paul Yowell, Comment, Through Rain, Snow, Heat, or Dark of Night: Does Private Express Delivery Constitute Service by Mail Under Federal Rule of Civil Procedure 5?, 46 Baylor L Rev 1147 (1994).

76 See Magnuson, 85 F3d at 1431 (holding Federal Express an invalid form of service under Rule 5); Audio Enterprises, Inc v B \& W Loudspeakers, 957 F2d 406, 409 (7th Cir 1992) (holding Federal Express an invalid form of service under Rule 4). See also Prince $v$ Poulos, 876 F2d 30, 32 n 1 (5th Cir 1989) (finding that Federal Express delivery is not a form of mail for purposes of Federal Rule of Appellate Procedure 25). But see United States $v$ Certain Real Property and Premises Known as 63-29 Trimble Road, 812 F Supp 332, 334 (E D NY 1992) (holding that service by Federal Express is sufficient for Rule 5 purposes since Rule 5, unlike Rule 4, does not require service by first class mail); Edmond $v$ United States Postal Service, 727 F Supp 7, 11 (D DC 1989) (stating without argument that Federal Express mailing satisfied service under Rule 5).

785 F3d 1424 (9th Cir 1996). 
Express was not adequate under Rule $5{ }^{78}$ The court reasoned that in 1937, when Rule 5 was adopted, "mail" could only have meant "U.S. Mail" because Federal Express did not exist at the time. ${ }^{79}$ Moreover, in order to be consistent with previous decisions, the court held that Federal Express does not constitute "mail" for the purposes of Rule $5^{80}$ because it is not conveyed under a public authority ${ }^{81}$ and because it is not considered "mail" for the purposes of Rule $4^{82}$ The definition of mail must be consistent under all the Federal Rules of Civil Procedure; otherwise, confusion among the courts would result. ${ }^{83}$

b) Fax service. ${ }^{84}$ A majority of courts holds that service by fax is not adequate under rules governing civil procedure because a fax cannot be characterized as "mail." ${ }^{85}$ For instance, in Salley $v$ Board of Governors, ${ }^{86}$ the court held that the plaintiff's fax transmission of discovery requests was inadequate under Rule 5(b). ${ }^{87}$ Although the court recognized that faxes may save time

Id at 1431 .

79 Id at 1430-31. Although Rule 4 did not contain a service by mail provision until 1983, Rule 5 has permitted service by mail since its adoption in 1937 .

${ }^{\infty}$ Id at 1430.

' Id. See also Prince, 876 F2d at $32 \mathrm{n} 1$ (holding that Federal Express is an impermissible means of filing briefs under FRAP 25(a), because "mail" must be delivered under a public authority).

* Magnuson, 85 F3d at 1430-31. See also Audio Enterprises, 957 F2d at 408-09 (finding that Federal Express does not constitute "mail" for the purposes of the pre-1993 Rule 4). Prior to 1993 , Rule 4 specifically provided for service by first class mail. See FRCP 4 (c)(2)(C)(ii) (1992). However, private express delivery service is not first class mail. Audio Enterprises, $957 \mathrm{F2d}$ at 408-09.

Magnuson, 85 F3d at 1431.

* See David A. Sokasits, Note, The Long Arm of the Fax: Service of Process Using Fax Machines, 16 Rutgers Comp \& Tech L J 531, 539-41, 554-57 (1990) (arguing, before the issue was considered by many courts, that service of process by fax is constitutionally sufficient and that rules governing procedure should be modified to facilitate fax service procedures).

es In the state law context, see Clater $v$ State, $266 \mathrm{Ga} 511,467$ SE2d 537, 539 (1996) (holding that fax transmission is not the same as registered or certified mail under the state's Interstate Agreement on Detainer statute); Cheek v FNF Construction, Inc, 112 Nev 1249, 924 P2d 1347, 1351 (1996) (holding that fax service was inadequate under the state equivalent to Rule 5 because the rule does not specify fax as a permissible means of service); Marshall $v$ State, 544 NYS2d 437, 438 (Ct Cl 1989) (holding that service by fax is not an authorized means for effecting service and no means other than those detailed in the appropriate rule are sufficient).

os 136 FRD 417 (M D NC 1991).

"Id at 419-20. However, the court also held that defendants implicitly waived their right to object to faxed requests by answering previously faxed requests. Id at 421 . See also In re Cirkinyan, 192 Bankr 643, 648 (D NJ 1996) (finding service by fax effective despite the lack of authority under Rule $5(\mathrm{~b})$ because defendants consented to service by knowingly and voluntarily accepting fax service as indicated by their request for retransmission of certain pages). 
and be more convenient to litigants, ${ }^{88}$ the court deferred to an authoritative determination on the procedural adequacy of faxes by the Advisory Committee on Rules. ${ }^{89}$ The court rejected the plaintiff's contentions that faxing is a form of electronic mail and therefore constitutes mail service and that fax service is equivalent to personal service because faxing is similar to leaving copies in a "conspicuous place" (the fax machine in an office). ${ }^{91}$ The court found that fax transmission "is similar to, but not the same as, personal delivery."

\section{INTERNET TECHNOLOGY AND THE LAW}

Just as litigants attempted to use fax to serve process well before rules committees considered the possibility, litigants will attempt to use internet technology to serve process before procedural rules are amended. In addition to the tremendous growth of internet use in American society, a number of legal developments convincingly foreshadow internet service. ${ }^{93}$

First, internet technology is already employed to give notice in other contexts. For instance, in several different class actions courts have ordered internet posting of notice. ${ }^{94}$ Even absent judicial decree, parties to class actions are employing internet technologies, usually web sites, to help meet notice requirements. ${ }^{95}$

136 FRD at $420 \mathrm{n} 2$.

Id at 420 .

so Rule 5 defines delivery as "handing [a copy] to the attorney or to the party; or leaving it at the attorney's or party's office with a clerk or other person in charge thereof; or, if there is no one in charge, leaving it in a conspicuous place therein; or, if the office is closed or the person to be served has no office, leaving it at the person's dwelling house or usual place of abode with some person of suitable age and discretion then residing therein." FRCP 5(b) (emphasis added).

st Salley, 136 FRD at 419.

92 Id at 420 .

93 Although the current use of technology in the legal process undoubtedly foreshadows increased future use of technology in the area, it should be noted that the Rule 4 context is different than those discussed below. As highlighted throughout this Comment, service of process under Rule 4 is held to the constitutional standard of due process and thus the use of technology in the Rule 4 context will likely be subject to higher standards.

' In such cases, internet posting is usually one of several methods employed for the purpose of giving notice. See Department of Motor Vehicles $v$ Superior Court, 78 Cal Rptr 2d 88, 93 (Cal App 1998) (summarizing the procedural history of the case and noting that the trial court ordered class notice posted on the internet); Jury Orders Web Page Notice of Class Action, West's Legal News (July 19, 1996), available at 1996 WL 402652 (discussing a Pennsylvania district court's order in In re: Valley of Lakes RICO Class Action Litigation requiring class notice to be posted on an internet home page: <http:/www.legalaction. $\operatorname{com} />$ ).

95 See In re Synthroid Marketing Litigation, 1998 US Dist LEXIS 12936, *11 n 9 (N D Ill) (mentioning that full notice of class action could be accessed through the internet); Prince George Center, Inc v United States Gypsum Co, 704 A2d 141, 144 (Pa Super 1997) 
Some state and local rules already provide for internet service of interlocutory papers, ${ }^{96}$ and Utah plans to institute a system allowing judges to issue arrest warrants electronically. ${ }^{97}$ Also, a court in the United Kingdom recently allowed a plaintiff to serve a defendant using email..$^{98}$ The defendant's physical location was unknown, so personal service and traditional alternative methods of service were impossible..$^{99}$

Second, electronic court filing is becoming increasingly popular. In 1996, Rule 5 was amended to allow federal courts, by local rule without Judicial Conference action, to permit the electronic filing, signing, and verification of documents. ${ }^{100}$ Many state and local courts also have adopted rules that authorize electronic filing procedures. ${ }^{101} \mathrm{~A}$ number of courts maintain their own web

(discussing the parties' use of the internet to post notice of settlement).

* See Cal R Los Angeles Super Ct Rule 18(g) (providing for electronic mail service on parties who execute contracts with the court for electronic filings); NM Dist Ct $R$ Civ $P$ Rule 1-005.2 (Michie 1999) (providing for service by electronic transmission, for example, email, but specifically not fax, on attorneys who agree to accept electronically transmitted documents and register their email addresses with the court). See also Neb Rev St § 444822 (1993 \& Supp 1997) (allowing a liquidator to give notice of liquidation by, among other things, electronic mail); NY Ct Rules $\S 218.3$ (1998) (authorizing notice to the capital defender's office of a judgment that includes a death sentence by, among other things, electronic mail, although the notice must be followed, within two business days, by first class mail notification of the sentence); Tenn Code Ann \& 36-5-807(b) (1996 \& Supp 1998) (allowing the Child Support Enforcement Department to serve requests, orders, and subpoenas on parties using, among other things, electronic mail).

${ }^{7}$ See Wendy R. Leibowitz, Courts Electrify Suits, Sparks Fly; New Rules Needed For E-Filings, Natl L J B6 (Sept 7, 1998).

* See Conley, Comment, 11 Temple Intl \& Comp L J at 408 (cited in note 4).

* See id at 409.

${ }^{100}$ FRCP 5(e) ("A court may by local rule permit papers to be filed, signed, or verified by electronic means that are consistent with technical standards, if any, that the Judicial Conference of the United State establishes. A paper filed by electronic means in compliance with a local rule constitutes a written paper for the purpose of applying these rules.").

${ }^{101}$ See Amendments to the Rules of Judicial Administration-Rule 2.090-Electronic Transmission and Filing of Documents, 681 S2d 698 (Fla 1996) (adopting an electronic court filing system for Florida courts); Cal R Los Angeles Super Ct Rule 18 (permitting electronic filing of documents with the court (1) by parties who execute a contract with the court including a promise not to send harmful material to the court's systems and (2) so long as all documents are digitally signed pursuant to Rule 18.01; fax filing is governed by a different rule); NM Dist Ct $R$ Civ P Rule 1-005.2(D) (permitting filing of papers by electronic transmission-but specifically not fax-with any court that adopts technical specifications for such transmissions); Clerk's Office Procedural Handbook E D Pa, Appendix W (1998) (describing how litigants can electronically submit civil and criminal documents with the court); <http://www.ncsc.dni.us/jeddi/jeddi.htm> (visited Mar 3, 1999) ("jeddi" is the abbreviation for judicial electronic document and data interchange used for court electronic filing procedures). See also B. Paul Cotter and John H. Messing, Electronic Court Filing in the Pima County Small Claims Court-Technical Parameters, Adopted Solutions, And Some of the Legal Issues Involved, 38 Jurimetrics J 397 (1998) (discussing in detail the electronic, via email, filing system of an Arizona small claims court); Joseph P. Zammit and Lynette A. Herscha, Litigation Issues in a Cyber World, 507 PLI/Pat 107, 133 
sites where individuals can obtain judicial opinions, information about fee changes, local rules, and other court notices. ${ }^{102}$ In fact, there are web pages dedicated entirely to specific cases. ${ }^{103}$

\section{INTERNET SERVICE OF PROCESS}

\section{A. Methods For Effecting Internet Service}

The internet can be employed in several different ways to effect service of process. The most obvious and direct manner is through the use of electronic mail. Actual service of process, as opposed to waiver of service, requires the plaintiff to serve the defendant with a copy of both the complaint and the summons; ${ }^{104}$ the summons must be signed by the clerk and bear the seal of the court. ${ }^{105}$ The requirements for the form of the summons could be met by establishing electronic summons-issuing procedures in which the clerk would authorize a summons with two digital signatures, ${ }^{106}$ one for the court and one for the clerk. The plaintiff could then effect service of process by forwarding to the defendant the official court-issued summons with an attached copy of the complaint in a universally readable format. ${ }^{107}$

Internet service of a request for waiver of formal service would be even easier to accomplish using the above described technology, since there is no need for the court's participation. ${ }^{108}$ With the request for waiver procedure, the serving party must send the defendant notice of the action accompanied by a request that the defendant waive service of summons and a copy of the

(1998) (mentioning an experiment with internet filing conducted by the Administrative Office of the US Courts).

${ }^{102}$ See <http:/www.courts/net> (visited Mar 3, 1999) (collecting links to state and federal court web sites).

${ }^{103}$ See, for example, <http://www.fenphen.cilp.org> (visited Nov 5, 1998) (containing orders and filings concerning In re Diet Drugs, 1998 US Dist LEXIS 5956 (E D Pa), and In Re Diet Drugs, 1998 US Dist LEXIS 18109 (E D Pa)).

${ }^{104}$ FRCP 4(d)(2).

${ }^{105}$ FRCP 4(a).

${ }^{100}$ Digital signatures are easy to obtain and have become commonplace in both business transactions and the judicial process. See, for example, <http:/www.verisign.com> (visited Apr 23, 1999) (selling digital signatures). All but three states have considered or enacted some variation of an electronic authentication law. See Commercial Law-Electronic Signatures: Lack of Uniformity Prevails Among State Electronic Authentication Statutes, 67 USLW 2051 (Aug 4, 1998). Many of these laws specifically provide that an electronic signature shall "have the same force and effect as a written signature." Tenn Code Ann \& 16-1-115 (1994 \& Supp 1998). See, for example, Miss Code Ann § 25-63-9 (1991 \& Supp 1997); Or Rev Stat \$ 192.840 (1997); Utah Code Ann § 46-3-403 (1998).

tor Text documents can be sent by email using universally readable formats, such as a rich text format ("RTF") version or a portable document format ("PDF") version.

${ }^{108}$ See note 65 for the partial text of Rule $4(d)$, which provides for waiver of service procedures. 
complaint. ${ }^{109}$ Rule 4 specifically requires that the waiver request be dispatched through "first-class mail or other reliable means."110 Significantly, the Advisory Committee Notes to Rule 4 anticipate the use of electronic means for communicating waiver requests. ${ }^{111}$ The waiver request must be accompanied by a "prepaid means of compliance in writing." ${ }^{\text {112 }}$ Electronic transmission of the waiver request easily meets this requirement, because the defendant's reply to the plaintiff's email is basically costless. ${ }^{113}$ One objection to electronically mailed service may be that the defendant could accidentally delete or lose the email; therefore, perhaps a better way to effect internet service would be to combine email with a web site. ${ }^{114}$ A plaintiff could send a defendant electronic mail that contains the contents of the complaint, a link to a web site, and a password. The password-protected web site would contain another copy of the complaint as well as the official summons, signed by the clerk and bearing the seal of the court. ${ }^{115}$ Since the defendant would be unable to make changes to the web site, he would be unable to "lose" the service.

\section{B. Evaluating the Elements of Internet Service}

1. Adequacy of internet service under existing rules.

Internet service will not satisfy the requirements for alternative service under Rule $4^{116}$ unless internet service is permissible under the appropriate state rule governing service. Absent a state rule explicitly permitting internet service, internet service may nonetheless be permissible under state rules if the state rules provide for mail service and email constitutes "mail" under those state rules. ${ }^{117}$ However, given the poor reception by courts to arguments that fax and private express delivery services are

${ }^{100}$ FRCP 4(d)(2).

${ }^{110} \mathrm{FRCP} 4(\mathrm{~d})(2)(\mathrm{B})$.

"'I FRCP 4(d)(2)(B) Advisory Committee Notes, 1993 Amendments ("[E]lectronic communications may be ... equally reliable and on occasion more convenient to the parties.").

${ }^{112}$ FRCP 4(d)(2)(G).

${ }^{113}$ See note 137 .

${ }^{11}$ Other ways of ensuring that a defendant does not accidentally lose electronic service include repeatedly sending the defendant copies of the service or making the email undeletable for a period of time.

${ }^{113}$ This is only one example. A discussion of every technical aspect of internet service of process and every possible combination of technology is far beyond the scope of this Comment.

${ }^{118}$ However, internet service will satisfy the waiver requirement since it is a reliable means of sending a waiver request.

${ }^{117}$ Note that the question is not whether email constitutes "mail" under the Federal Rules of Civil Procedure but whether email constitutes "mail" under the state rule. 
mail, courts are not likely to accept that electronic mail is "mail" under rules governing notice procedures. Electronic mail is not conveyed under a public authority ${ }^{118}$ and was probably not in the minds of the drafters of most rules of procedure. ${ }^{119}$

However, the case for electronic mail may be stronger than the case for fax or private express delivery services because electronic mail will soon be conveyed under the authority of the United States Postal Service ("USPS"). The USPS has recently unveiled several plans to enter the electronic mail market, namely "PostOffice Online" and "Post E.C.S." ${ }^{\text {"120 }}$ PostOffice Online will allow customers to send email to the USPS; the USPS will then convert the email to paper via commercial printers ${ }^{121}$ and deliver the mail by traditional methods. ${ }^{122}$ Post E.C.S., on the other hand, will convey electronic mail in its electronic format under the authority of the USPS. Post E.C.S. is the result of joint efforts between the USPS, the Canada Post, and France's La Poste. ${ }^{123}$ The system will offer security, tracking, delivery confirmation, portable document format technology, and sender and receiver authentication. ${ }^{124}$

Even if electronic mail is not "mail" under applicable rules governing procedure, electronic mail (and other procedures using the internet) may be adequate as a means of serving process under state rules governing procedure. Internet service may be adequate in jurisdictions where courts are allowed to prescribe alternative service methods ${ }^{125}$ and do so to permit internet service. Furthermore, despite the fact that internet service is not yet provided for in service rules, actual notice jurisdictions are likely to find internet service of process valid, because those jurisdictions suspend the procedural requirements for service so long as the

\footnotetext{
${ }^{118}$ See note 81 and accompanying text.

${ }^{111}$ See text accompanying note 79.

${ }^{120}$ See <http://www.usps.gov/news/press/98/98090new.htm> (visited Mar 3, 1999) (released Sept 2, 1998).

${ }^{121}$ See Prequalification for Mailing Online for Chicago, $I l$, Los Angeles, Ca, and New York, NY, Comm Bus Daily (Oct 20, 1998) (soliciting qualified printing services to activate the online mailing program).

${ }^{122}$ See <http:/www.usps.gov/news/press/98/98090new.htm> (visited Mar 3, 1999).

${ }^{123}$ See id.

${ }^{124}$ See id. See also Shawn McCarthy, Canada Post Builds Digital Mailbox Strategy / The Crown Corporation is Slowly Adapting to New Technologies to Modernize Itself and Avoid Becoming a Dinosaur, Globe \& Mail (Toronto) B15 (June 23, 1998) (discussing the joint venture with the USPS and noting that the system promises to offer digital signatures and proof of delivery and receipt).

${ }^{125}$ See, for example, Iowa R Civ $P 56.2$ (permilting alternative service "in any manner consistent with due process of law prescribed by order of the court ${ }^{\text {") }}$.
} 
defendant's constitutional rights to due process are not compromised. ${ }^{126}$

It is likely that, given the recent changes in local and state rules governing electronic filing and service of papers other than initial summons, some states will amend their service rules to allow explicitly for internet service of process. Such amendments will solve any potential conflicts between the constitutional and rule-based requirements for service. Conflicts between the requirements for service will arise in situations where the rule governing service does not permit internet service but the circumstances of the particular case ${ }^{127}$ dictate that internet service is more reliable and cost effective (and therefore more "reasonable") than other available alternatives. Given the majority rule that service of process must meet both constitutional and rule-based requirements, courts should not construe service procedures liberally to allow internet service. In the absence of amendments to local and state rules, courts should only allow internet service in those instances where it is necessary to effect actual notice and other methods appropriate under the rule have already been attempted.

2. The constitutional element of internet service.

The Supreme Court assesses the constitutionality of an alternative means of service by applying a reasonableness standard. ${ }^{128}$ The reasonableness standard can be used to find that a specific means of alternative service is constitutionally sufficient, whether it results in actual notice or not, and that a specific means of alternative service is constitutionally insufficient because other available alternative service methods are cost effective and are more likely to result in actual notice. The standard requires an assessment of whether the chosen means of alternative service was "reasonably calculated, under all the circumstances" to afford the defendant actual notice of the action. ${ }^{129} \mathrm{Un}$ der this analysis, there are many instances in which internet

\footnotetext{
${ }^{228}$ See notes 56-57 and accompanying text.

${ }^{17}$ For instance, if the defendant cannot be reached at home or through personal service, and if the defendant is a frequent internet user, then the circumstances of the case may well dictate that internet service is appropriate and even necessary. This conclusion is further strengthened if the defendant has a substantial interest at stake, since due process factors are likely to balance in favor of more extensive notice procedures. The factspecific inquiry for determining whether an alternative service method is appropriate eliminates problems that might arise if internet service were uniformly permitted, yet not every defendant had access to the internet.

${ }_{12}$ See Part II.A.1.

${ }^{10}$ Mullane, 339 US at 314.
} 
service is constitutionally sufficient, other instances in which internet service is superior to traditional forms of service, and even some instances in which internet service is constitutionally required.

a) Internet service is constitutionally sufficient. Internet service, with some component of electronic mail, will often be sufficient under the Constitution. Because many individuals use electronic mail, ${ }^{130}$ which is reliable and secure, it will frequently be a method of service reasonably calculated to reach a defendant and thus to result in actual notice. To the extent that internet service results in actual notice, both a defendant's due process rights and the constitutional requirement for service are met. In fact, internet service may be the alternative method of service most likely to result in actual notice. If this is true, then internet service exceeds the constitutional standard, which only requires a method of service reasonably calculated, given the circumstances, to reach the defendant.

b) Internet service may be superior to other forms of service. In today's world, internet service, effected through some combination of the internet and email, may be more likely to result in actual notice than traditional mail or even personal service. ${ }^{131}$ Electronic mail has significantly reduced the amount of mail delivered each year by the United States Postal Service, demonstrating a trend toward electronic communication and away from traditional paper-based forms of communication. ${ }^{132}$ Many individuals check their electronic mail remotely. ${ }^{133}$ Thus, a piece of email may well reach the defendant instantaneously wherever she may be,

\footnotetext{
${ }^{130}$ The day when all Americans read email may be around the corner. In its first two years, Hotmail, Microsoft's free email provider, issued fifteen million accounts. Danielle Reed, Takeoffs and Landings: Lighter Mail, Wall St J W7 (June 5, 1998).

${ }^{131}$ See <http://www.cato.org/pubs/pas/pa-146.html> (visited Mar 3, 1999) (discussing the frequency of lost mail and the inefficient, slow delivery of mail by the USPS). Given that electronic mail is more likely to reach the served person than traditional mail, electronic mail service may be a viable option for service on the government. Currently, one cannot request the government to waive service, in part, as the Advisory Committee notes, because the mail rooms in government offices are inadequate. FRCP 4(d) Advisory Committee Notes. The Attorney General could easily set up an internet account for the sole purpose of receiving process. This idea transfers over into the corporate context where a single agent is often designated to accept all service. The designated service agent could either set up a specific internet account for receipt of service or advertise her own account for receipt of service.

${ }^{132}$ In commenting on the USPS's decreased first class mail business, the American Shipper notes that some experts predict by the year 2000 about 25 percent of mail will be electronically distributed. Express Carriers Support Postal Reform: UPS, FedEx Back McHugh's Bill To Restructure Postal Service, Am Shipper 92 (June 1, 1998).

${ }^{135}$ There are even modems that use cellular technology and allow internet users to check their mail from anywhere serviced by such technology.
} 
whereas a piece of "first class" mail may sit unread in a defendant's mailbox for days while the defendant is out of town, or a process server may be unable to locate a defendant. Moreover, traditional mail may be easier to lose than email. ${ }^{134}$ Finally, electronic mail offers a way for the plaintiff to identify whether the defendant has at least opened the mail containing the complaint, ${ }^{135}$ a verification of actual notice that neither traditional mail nor personal service can offer.

Internet service has the potential to be more secure, and thus more reliable, than any form of service employed in the past. Digital signatures, which can be used on electronic mails and documents posted on web sites, are harder to forge than traditional signatures. ${ }^{136}$ Digital signatures make electronic service more secure than service by fax, since it is easy to falsely append one's signature to a faxed document. Moreover, unlike traditional mail, where one mail box or mail room may serve a number of people, one internet account usually serves one person. Thus, if electronic mail is employed to send service, the sender can be reasonably assured that only the owner of the account will receive the service.

\footnotetext{
${ }^{13}$ See, for instance, Greene, 456 US at 460 (O'Connor dissenting) (commenting on the unreliability of mail: "It is no secret, after all, that unattended mailboxes are subject to plunder by thieves"). In fact, it seems that electronic mail is difficult to lose when parties most want it to disappear. Two recent high profile cases illustrate the permanence of email: the Justice Department's antitrust action against Microsoft and the Independent Counsel's investigation of President Clinton. See Paul Van Slambrouch, E-Mail Culture Goes To Court: Microsoft Case Shows How Perception of E-Mail as Private and Casual Clashes with Efforts to Use it in Litigation, Christian Sci Monitor 1 (Oct 23, 1998); June Kronholz and Rebecca Quick, The Lewinsky Story: Is a Tale Spun Out Across Cyberspace and Therein Lies a Drawback of E-Mail: It's Difficult To Ever Really Delete It, Wall St J Al (Sept 22, 1998).

There are a number of reasons why electronic mail is difficult to lose. The most important is backups. When a person downloads mail to her computer, the mail may not have been erased from the server, or the central server may have created a backup of the mail. Moreover, when a user deletes mail from her personal computer, the mail may continue to exist in backup directories or in the computer's memoxy, marked for deletion, until there is a need to store something else in that memory.

${ }^{13 s}$ For instance, in UNIX systems one can use the "finger suserid >" command to determine whether a user has any unread mail. The finger command tells the issuer when a particular user last logged on, where the user logged on from, when the user last read their email, and if the user has any unread email. Commands such as this can also provide a plaintiff seeking to use internet service with information about the defendant's internet habits.

${ }^{138}$ See Information Security Committee Section of Science and Technology, American Bar Association, Public Key Infrastructure Symposium: Tutorial, 38 Jurimetrics J 243, 249 (1998) (noting that it is "computationally infeasible" to discover the code behind a digital signer's private signature). Digital signatures are also exceedingly reliable, and there is far less risk of undetected forgery with digital signatures than with traditional signatures or less secure forms of electronic signatures. Id at 252.
} 
Finally, internet service is cheaper ${ }^{137}$ than either traditional mail or personal service; thus internet service promotes the Advisory Committee's desire to limit the overall costs of service. ${ }^{138}$ If internet service entails sending electronic mail from an account already purchased and paid for, then internet service is nearly costless to the plaintiff, especially in comparison with the cost of first class mail, certified mail, or a process server. Moreover, because an email user can reply to an email without incurring costs, replying to the plaintiff's service is "prepaid"; therefore, a plaintiff can use email to send a waiver request to the defendant and meet Rule 4(d)(2)(G)'s requirement of a "prepaid means of compliance in writing."

c) Internet service may be constitutionally required. In some cases, internet service may even be constitutionally required. Given that email is virtually costless once one has internet access, the requirement to employ internet service will turn on the nature of the plaintiff's claims, the defendant's internet habits, ${ }^{139}$ and the probable effectiveness of other available means of service. ${ }^{140}$ For instance, internet service may be constitutionally required if the parties' sole contact is through the internet, as in the English case discussed above. ${ }^{141}$ In that case, because the defendant's physical location was unknown, personal service was impossible; internet service was thus the only "reasonably calculated," cost effective means of informing the defendant of the action. Intermet service might also be constitutionally required if the plaintiff's claim arises from the defendant's internet activities. ${ }^{142}$ In such cases internet service will be an obvious alterna-

\footnotetext{
${ }^{15}$ In many instances, email service is free. There are over six hundred free email providers. See <http//www.emailaddresses.com > (visited Mar 3, 1999).

${ }^{138}$ See, for instance, FRCP 4(d) Advisory Committee Notes, 1993 Amendments (discussing the purpose of the mail service waiver provisions, "to eliminate the costs of service of a summons on many parties").

${ }^{139}$ In many instances the plaintiff may already be aware of the defendant's internet habits, for instance, if the plaintiff is an employee or a business associate of the defendant. However, even if the plaintiff is not personally aware of the defendant's internet habits she can discover them by employing an internet process server or through use of readily available internet tools. See note 135 .

${ }^{140} \mathrm{~A}$ full due process analysis requires a consideration of the costs to the government of instituting the procedure. See Part II.A. The only real cost to the government of allowing formal service of process by the internet will be the cost of digital signatures for the courts, the costs that will be incurred by courts in learning to use new technology, and other general administrative costs. The costs of the signatures is minimal and, arguably, courts must at some point undergo the pains of learning new technology (as many already are), the costs of which may well be outweighed by the efficiencies new technology will provide.

${ }^{11}$ See text accompanying notes 98-99.

${ }^{102}$ For instance, there have been a number of trademark infingement cases in which
} 
tive (or supplement) to personal service or other traditional forms of service, just as mail was an obvious alternative in both Greene and Mullane. Moreover, in the event that alternative methods of service other than the internet fail, or are likely to fail, the reasonableness of internet service and its constitutional preferability-at least as a supplement to the method chosen -will be demonstrated..$^{143}$

The constitutionality of internet service of process will become increasingly clear as the number of Americans who rely on the internet as their principal means of communication increases. If it is obvious that one's chosen medium for communication is the internet, then it is also obvious that the form of notice most "reasonably calculated" to reach the defendant is also the internet.

\section{CONCLUSION}

The validity of internet service under current rules governing procedure must be assessed on a case by case basis. Given the popularity of the internet in our society, internet service of process will often be constitutionally adequate and may even be constitutionally required. Moreover, under certain state rules governing alternative forms of service, internet service may already be procedurally adequate. Because internet service is efficient, secure, reliable, and, in some instances, constitutionally necessary, rules governing service should permit internet service.

the plaintiff has claimed that the defendant's domain name infringes on the plaintiff's trademark. A domain name, in short, is what comes before the ".edu" or ".com." In www.nike.com, "nike" is the domain name. See, for instance, Panavision Intl, LP v Toeppen, 141 F3d 1316, 1319 (9th Cir 1998) (disputing defendant's use of the domain names "panavision" and "panaflex"); Hasbro, Inc v Internet Entertainment Group, Ltd, 1996 US Dist LEXIS 11626, *2-3 (W D Wash) (disputing defendant's use of "candyland" as a domain name). See generally Danielle Weinberg Swartz, Comment, The Limitations of Trademark Law in Addressing Domain Name Disputes, 45 UCLA L Rev 1487 (1998).

${ }^{13}$ See, for example, Greene, 456 US at $456 \mathrm{n} 9$ (concluding that mail service, as a supplement to posted service, was "constitutionally preferable to posted service alone"). It is not difficult to imagine a Greene-type challenge to an alternative method of service arising today. Even though at the time of Greene mail service was not a traditional option, just as internet service is not a traditional option today, the Court resorted to its common knowledge of the popular methods of communication of the day to find that posted notice was not reasonably calculated to give notice. Similarly, if a plaintiff today attempted to leave copies at the home of a defendant under Rule 4 as an alternative means of service, a court may find that the attempt was insufficient because of the availability of email, an obvious, cost effective, reliable means of affording notice. 


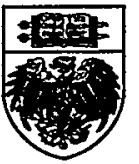

